M edia Informatika, Vol. 2, N o. 1, Juni 2004, 1-10

ISSN : 0854-4743

\title{
FUZZY QUANTIFICATION THEORY I UNTUK ANALISIS HUBUNGAN ANTARA PENILAIAN KINERJA DOSEN OLEH MAHASISWA, KEHADIRAN DOSEN, DAN NILAI KELULUSAN MAHASISWA
}

\author{
Sri Kusumadewi \\ Jurusan Teknik Informatika, Fakultas Teknologi Industri,U niversitas Islam Indonesia \\ Jl. Kaliurang Km. 14 Y ogyakarta 55501
}

Telp. (0274) 895287 ext. 122, Faks. (0274) 895007 ext. 148

E-mail: cicie@fti.uii.ac.id

\begin{abstract}
ABSTRAK
Fuzzy quantification theory I, adalah suatu metode untuk menentukan hubungan antara variabel kualitatif yang diberikan dengan nilai antara 0 sampai 1 , dan variabelvariabel numeris dalam fuzzy group yang diberikan dalam sampel. Pada penilitian ini, fuzzy quantification theory akan digunakan untuk menentukan seberapa besar faktorfaktor kualitatif penilaian mahasiswa terhadap kinerja dosen Jurusan Teknik Informatika Universitas Islam Indonesia, mempengaruhi hubungan antara kehadiran dosen dan nilai akhir mahasiswa. Hasil penelitian menjukkan bahwa faktor kemampuan dosen mendorong mahasiswa untuk berperan aktif memiliki pengaruh yang paling tinggi diantara faktorfaktor yang lainnya dalam kaitannya dengan pengaruh antara kehariran dosen mengajar dengan nilai kelulusan mahasiswa $\geq$ 'B'. Pengaruh ini akan sangat kuat apabila kehadiran dosen mengajar lebih dari 10 kali.
\end{abstract}

Kata kunci: fuzzy quantification theory, fuzzy group, kualitatif

\section{PENDAHULUAN}

Tercapainya tujuan proses belajar mengajar dalam suatu perguruan tinggi tidak terlepas dari peranan dosen dan mahasiswa. Keaktivan para dosen dalam memberikan perkuliahan dan keaktifan mahasiswa dalam mengikuti proses belajar mengajar menjadi kunci utama suksesnya proses belajar mengajar. Suksesnya proses belajar mengajar, bagi mahasiswa, dapat dilihat dengan alat ukur berupa nilai akhir yang diperoleh. Biasanya, seorang mahasiswa dikatakan memiliki nilai baik dalam suatu matakuliah, apabila mahasiswa tersebut mendapatkan nilai lebih dari atau sama dengan ' $B$ '. Demikian pula, seorang dosen dikatakan sukses dalam proses belajar mengajar, apabila nilai kinerja yang diperolehnya juga baik.

Jurusan Teknik Informatika Fakultas Teknologi Industri Universitas Islam Indonesia selama ini telah menerapkan evaluasi terhadai kinerja dosen dengan menggunakan alat ukur yang dikenal dengan Nilai Kinerja Dosen (NKD). Salah satu variabel yang digunakan untuk menghitung NKD adalah penilaian dari 
mahasiswa yang mengambil matakuliah yang diampu oleh dosen yang bersangkutan. Penilaian oleh mahasiswa dilakukan melalui pengisian kuisioner. Pada semester genap tahun akademik 2003/2004, ada 8 pertanyaan yang diberikan dalam kuisioner, yaitu: kejelasan $\&$ semangat dosen dalam memberikan kuliah; kemampuan dosen menguasai kelas; kemampuan dosen mendorong mahasiswa untuk berperan aktif; tanggapan \& kejelasan dosen menjawab pertanyaan mahasiswa; kemampuan dosen memotivasi mahasiswa untuk belajar; hubungan contoh soal dan tugas dengan materi yg diberikan; disiplin dosen terhadap alokasi waktu yang diberikan; dan kesesuaian materi kuliah dengan silabus/ Satuan A cara Perkualiahan (SAP). Setiap pertanyaan memiliki nilai antara 1 (buruk), sampai 4 (sangat baik). Selain penilaian mahasiswa yang bersifat kualitatif, NKD juga dipengaruhi oleh variabel kehadiran dosen dalam mengajar, yang jelas terukur.

Untuk menghubungkan antara faktor kualitatif dan kuantitatif, dapat digunakan fuzzy quantification theory. Ada 3 metode fuzzy quantification theory. Fuzzy quantification theory I, akan menentukan hubungan antara variabel kualitatif yang diberikan dengan nilai antara 0 sampai 1 , dan variabel-variabel numeris dalam fuzzy group yang diberikan dalam sampel.

Pada penelitian ini, akan dicoba untuk mengukur pengaruh faktor-faktor kualitatif (penilaian mahasiswa) terhadap hubungan antara kehadiran dosen dengan prosentase nilai kelulusan mahasiswa $\geq$ ' $B$ '.

\section{TUJUAN PENELITIAN}

Penelitian ini bertujuan untuk menentukan seberapa besar faktor-faktor kualitatif penilaian mahasiswa terhadap kinerja dosen Jurusan Teknik Informatika, mempengaruhi hubungan antara kehadiran dosen dan nilai akhir mahasiswa, dengan menggunakan fuzzy quantification theory I.

\section{DASAR TEORI}

\subsection{Teori Q uantifikasi}

Secara umum metode kuantifikasi menggunakan data-data kasar seperti hasil evaluasi dan pendapat orang yang mana kuantitas dan pemahanan tentang data-data tersebut tidak secara normal diekspresikan secara numeris. Biasanya, suatu pendapat atau evaluasi terhadap suatu aktivitas akan direpresentasikan dalam bentuk kualitatif secara linguistik, seperti: baik, cukup, buruk, puas, dll. Padahal sebenarnya, untuk membandingkan pendapat atau evaluasi akan lebih mudah apabila ekspresi yang berbentuk kualitatif tersebut diganti dengan bentuk numeris. Untuk keperluan tersebut, maka dibutuhkan metode kuantifikasi. Fuzzy quantification theory adalah metode untuk mengendalikan data-data kualitatif dengan menggunakan teori himpunan fuzzy. Pengendalian disini lebih dimaksudkan untuk menjelaskan kejadian-kejadian fuzzy menggunakan nilai dalam rentang $[0,1]$ yang mengekspresikan pendapat-pendapat secara kualitatif (Kusumadewi, 2004). 
A pabila terdapat sampel data $x_{k}(k=1,2, \ldots, n)$, dengan derajat keanggotaan pada fuzzy group $B$ adalah $\mu_{B}\left[x_{k}\right]$, dan terdapat $S$ fuzzy group, maka dapat dicari total mean $m$ dan mean $m_{B i}(i=1,2, \ldots, S)$ sebagai berikut:

$$
\begin{aligned}
& m=\frac{1}{N}\left\{\sum_{i=1}^{S} \sum_{k=1}^{n} x_{k} \mu_{B i}[x]\right\} \\
& m_{B i}=\frac{1}{N\left(B_{i}\right)}\left\{\sum_{i=k}^{n} x_{k} \mu_{B i}[x]\right\}
\end{aligned}
$$

dengan

$$
\begin{aligned}
& N(B)=\sum_{k=1}^{n} \mu_{B}\left[x_{k}\right] \\
& N=\sum_{i=1}^{S} N\left(B_{i}\right)
\end{aligned}
$$

Total variansi $T$, variansi antar fuzzy group $B$, dan variansi dalam suatu fuzzy group E dapat ditentukan sebagai berikut:

$$
\begin{aligned}
& T=\sum_{k=1}^{n} \sum_{i=1}^{s}\left(x_{k}-m\right)^{2} \mu_{B i}\left[x_{k}\right] \\
& B=\sum_{k=1}^{n} \sum_{i=1}^{s}\left(m_{B i}-m\right)^{2} \mu_{B i}\left[x_{k}\right] \\
& E=\sum_{k=1}^{n} \sum_{i=1}^{s}\left(x_{k}-m_{B i}\right)^{2} \mu_{B i}\left[x_{k}\right]
\end{aligned}
$$

dalam hal ini, $\mathrm{T}=\mathrm{B}+\mathrm{E}$.

\subsection{Fuzzy Quantification Theory I}

Tujuan dari Fuzzy Q uantification Theory I (analisis regresi kualitatif) adalah menentukan hubungan antara variabel kualitatif yang diberikan dengan nilai antara 0 sampai 1 , dan variabel-variabel numeris dalam fuzzy group yang diberikan dalam sampel.

Tabel 1 Karakteristik Fuzzy Q uantification Theory I

\begin{tabular}{|c|c|c|c|}
\hline $\begin{array}{c}\text { No. } \\
(\mathrm{k})\end{array}$ & $\begin{array}{c}\text { External data } \\
(\mathrm{y})\end{array}$ & $\begin{array}{c}\text { Kategori } \\
\mathrm{A}_{1} \ldots \mathrm{A}_{\mathrm{i}} \ldots \mathrm{A}_{\mathrm{P}}\end{array}$ & $\begin{array}{c}\text { Fuzzy group } \\
(\mathrm{B})\end{array}$ \\
\hline 1 & $\mathrm{y}_{1}$ & $\mu_{1}(1) \ldots \mu_{\mathrm{i}}(1) \ldots \mu_{\mathrm{P}}(1)$ & $\mu_{\mathrm{B}}(1)$ \\
2 & $\mathrm{y}_{2}$ & $\mu_{1}(2) \ldots \mu_{\mathrm{i}}(2) \ldots \mu_{\mathrm{P}}(2)$ & $\mu_{\mathrm{B}}(2)$ \\
3 & $\mathrm{y}_{3}$ & $\mu_{1}(3) \ldots \mu_{\mathrm{i}}(3) \ldots \mu_{\mathrm{P}}(3)$ & $\mu_{\mathrm{B}}(3)$ \\
$\mathrm{k}$ & $\mathrm{y}_{\mathrm{k}}$ & $\mu_{1}(\mathrm{k}) \ldots \mu_{\mathrm{i}}(\mathrm{k}) \ldots \mu_{\mathrm{P}}(\mathrm{k})$ & $\mu_{\mathrm{B}}(\mathrm{k})$ \\
$\mathrm{N}$ & $\mathrm{y}_{\mathrm{n}}$ & $\mu_{1}(\mathrm{n}) \ldots \mu_{\mathrm{i}}(\mathrm{n}) \ldots \mu_{\mathrm{P}}(\mathrm{n})$ & $\mu_{\mathrm{B}}(\mathrm{n})$ \\
\hline
\end{tabular}


Pada Tabel 1 menunjukkan karakteristik Fuzzy Quantification Theory I. Pada tabel tersebut terdapat $\mathrm{n}$ buah sampel. External Standard $(\mathrm{y})$ menunjukkan fungsi tujuan. $y_{k}$ adalah fungsi tujuan dari sampel ke-k. $\mu_{i}(k)$ adalah derajat suatu tanggapan terhadap kategori kulitatif ke-i $(i=1,2, \ldots$, P) pada sampel ke-k yang diberi nilai $[0,1]$.

Fuzzy Quantification Theory I sama halnya menentukan suatu fungsi linear dari beberapa kategori (Terano et al., 1992):

$$
y(k)=\sum_{i=1}^{p} a_{i} \mu_{i}(k)
$$

Persamaan 1, tentu saja diharapkan variasi tujuan memberikan nilai error yang sangat kecil. Untuk keperluan tersebut, dapat disusun bentuk matriks:

$$
y^{\prime}=\left[y_{1}, y_{2}, \ldots, y_{n}\right]
$$

$G=\left[\begin{array}{ccc}\mu_{\mathrm{B}}(1) & & 0 \\ & \ddots & \\ 0 & & \mu_{\mathrm{B}}(\mathrm{n})\end{array}\right]$

$\mathrm{X}=\left[\mu_{\mathrm{i}}(\mathrm{k})\right]=\left[\begin{array}{ccccc}\mu_{1}(1) & \cdots & \mu_{\mathrm{i}}(1) & \cdots & \mu_{\mathrm{P}}(1) \\ \vdots & & \vdots & & \vdots \\ \mu_{1}(\mathrm{k}) & \cdots & \mu_{\mathrm{i}}(\mathrm{k}) & \cdots & \mu_{\mathrm{P}}(\mathrm{k}) \\ \vdots & & \vdots & & \vdots \\ \mu_{1}(\mathrm{n}) & \cdots & \mu_{\mathrm{i}}(\mathrm{n}) & \cdots & \mu_{\mathrm{P}}(\mathrm{n})\end{array}\right]$

$a^{\prime}=\left[a_{1}, a_{2}, \ldots, a_{n}\right]$

Dengan demikian, error variance $\sigma_{\mathrm{B}}^{2}$ untuk fuzzy group B adalah

$\sigma_{B}^{2}=\frac{1}{N(B)}(y-X a)^{\prime} G(y-X a)$

dari

$\frac{\partial \sigma_{B}^{2}}{\partial a}=-2 X^{\prime} G y+2 X^{\prime} G X a=0$

Bobot kategori a yang meminimumkan error variance diberikan dengan persamaan sebagai berikut:

$$
\mathrm{a}=\left(X^{\prime} G X\right)^{-1} X^{\prime} G y
$$

4 Kusumadewi - Fuzzy Q uantification Theory I untuk A nalisis H ubungan A ntara Penilaian Kinerja ... 
Untuk mendapatkan pengaruh setiap kategori pada variabel $\mathrm{y}$, apabila perubahan pada kategori-kategori yang lain bersifat tetap dapat dilihat melalui koefisien korelasi parsial.

Fuzzy mean dan fuzzy covariance untuk kategori ke-i dan $y(k)$ adalah sebagai berikut:

$$
\begin{aligned}
& r_{\mathrm{ij}}=\frac{\sigma_{\mathrm{ij}}}{\sqrt{\sigma_{\mathrm{ii}} \sigma_{\mathrm{jj}}}} \\
& r_{\mathrm{iy}}=\frac{\sigma_{\mathrm{iy}}}{\sqrt{\sigma_{\mathrm{ii}} \sigma_{\mathrm{yy}}}}
\end{aligned}
$$

Disini, $X_{i}(k)=a_{i} \mu_{i}(k)$. Dengan menggunakan covariance tersebut, koefisien korelasi fuzzy rij dan riy dapat dicari sebagai berikut:।

$$
\begin{aligned}
& \bar{X}_{i}=\frac{1}{N}\left\{\sum_{r=1}^{M} \sum_{k=1}^{n} x_{i}(k) \mu_{B r}(k)\right\} \\
& \bar{y}=\frac{1}{N}\left\{\sum_{r=1}^{M} \sum_{k=1}^{n} y(k) \mu_{B r}(k)\right\} \\
& \sigma_{i j}=\frac{1}{N}\left\{\sum_{r=1}^{M} \sum_{k=1}^{n}\left(x_{i}(k)-\bar{X}_{i}\right)\left(x_{j}(k)-\bar{X}_{j}\right) \mu_{B r}(k)\right\} \\
& \sigma_{i y}=\frac{1}{N}\left\{\sum_{r=1}^{M} \sum_{k=1}^{n}\left(x_{i}(k)-\bar{X}_{i}\right)\left(y(k)-\bar{y}_{j}\right) \mu_{B r}(k)\right\} \\
& \sigma_{y y}=\frac{1}{N}\left\{\sum_{r=1}^{M} \sum_{k=1}^{n}\left(y(k)-\bar{y}_{j}\right)^{2} \mu_{B r}(k)\right\}
\end{aligned}
$$

Dari sini dapat dibentuk metriks $\mathrm{R}$ dengan elemen-elemen sebagai berikut:

$$
R=\left[\begin{array}{lllll}
1 & r_{12} & \cdots & r_{1 k} & r_{1 y} \\
r_{21} & 1 & \cdots & r_{12} & r_{2 y} \\
\vdots & \vdots & & \vdots & \vdots \\
r_{k 1} & r_{k 2} & \cdots & 1 & r_{\text {Ky }} \\
r_{y 1} & r_{y 2} & \cdots & r_{y k} & 1
\end{array}\right]
$$

Invers dari matriks R adalah: 


$$
R^{-1}=\left[\begin{array}{lllll}
r^{11} & r^{12} & \cdots & r^{1 k} & r^{1 y} \\
r^{21} & r^{22} & \cdots & r^{2 k} & r^{2 y} \\
\vdots & \vdots & & \vdots & \vdots \\
r^{k 1} & r^{k 2} & \cdots & r^{k K} & r^{k y} \\
r^{y 1} & r^{y 2} & \cdots & r^{y k} & r^{y y}
\end{array}\right]
$$

Kemudian variabel y dan koefisien korelasi parsialnya, $r_{i y}$ dengan $i=1,2, \ldots$, $\mathrm{i}-1, \mathrm{i}+1, \ldots, \mathrm{K}$ adalah:

$$
r^{i y}=\frac{-r^{i y}}{\sqrt{r^{i i} r^{y y}}}
$$

Koefisien korelasi parsial ini menunjukkan pengaruh variabel ke-i pada variabel y apabila variabel lainnya tetap.

\section{METODOLOGI PENELITIAN}

Penelitian dilakukan melalui langkah-langkah sebagai berikut:

a. Penentuan eksternal data, kategori, dan fuzzy group.

b. Penyelesaian masalah dengan memproses data input pada poin (a) menggunakan fuzzy quantification theory I.

c. Analisis terhadap setiap faktor (fuzzy group).

\section{HASIL PENELITIAN}

\subsection{Penentuan eksternal data, kategori, dan fuzzy group}

Pada penelitian ini, digunakan data hasil evaluasi kinerja dosen, jumlah kehadiran, dan distribusi nilai akhir mahasiswa di Jurusan Teknik Informatika pada semester genap tahun akademik 2003/ 2004. Data tersebut seperti terlihat pada Tabel 2.

\begin{tabular}{|c|c|c|c|c|c|c|c|c|c|c|c|c|}
\hline \multirow{2}{*}{ No } & \multirow{2}{*}{$\begin{array}{c}\text { Kode } \\
\text { matakuliah }\end{array}$} & \multirow{2}{*}{ Kelas } & \multirow{2}{*}{$\begin{array}{l}\text { Jumlah } \\
\text { kehadiran }\end{array}$} & \multirow{2}{*}{$\begin{array}{c}\text { \%Lulus } \\
>=\mathrm{B}\end{array}$} & \multicolumn{8}{|c|}{ Hasil penilaian mahasiswa* } \\
\hline & & & & & N1 & N2 & N3 & N4 & N5 & N6 & N7 & N8 \\
\hline 1 & 52300521 & $a$ & 11 & 0,00 & 2,87 & 2,73 & 2,87 & 3,00 & 2,87 & 3,00 & 2,73 & 3,00 \\
\hline 2 & 52300521 & $\mathrm{~b}$ & 11 & 4,17 & 2,53 & 2,53 & 2,40 & 2,73 & 2,47 & 2,93 & 2,80 & 2,93 \\
\hline 3 & 52300521 & C & 12 & 3,66 & 2,80 & 2,87 & 2,60 & 3,07 & 2,60 & 2,87 & 2,67 & 3,00 \\
\hline 4 & 52300521 & $\mathrm{~d}$ & 12 & 10,71 & 2,87 & 2,93 & 2,67 & 3,00 & 2,87 & 3,07 & 2,87 & 3,07 \\
\hline 5 & 52300721 & $a$ & 12 & 17,05 & 3,21 & 3,14 & 2,79 & 3,14 & 2,79 & 2,93 & 3,07 & 3,07 \\
\hline 6 & 52300721 & $\mathrm{~b}$ & 12 & 21,35 & 3,36 & 3,29 & 2,71 & 3,07 & 2,93 & 3,14 & 3,21 & 3,21 \\
\hline 7 & 52300721 & c & 11 & 19,77 & 2,93 & 3,14 & 2,86 & 3,00 & 2,93 & 3,07 & 2,86 & 3,07 \\
\hline 8 & 52300721 & $d$ & 12 & 41,67 & 2,33 & 2,40 & 2,53 & 2,47 & 2,53 & 2,87 & 2,40 & 2,73 \\
\hline 9 & 52303331 & $a$ & 11 & 88,41 & 3,69 & 3,54 & 3,46 & 3,54 & 3,31 & 3,38 & 3,31 & 3,46 \\
\hline 10 & 52303331 & $b$ & 10 & 73,91 & 3,69 & 3,54 & 3,46 & 3,46 & 3,23 & 3,38 & 3,31 & 3,38 \\
\hline 11 & 52303331 & C & 12 & 73,33 & 2,47 & 2,33 & 2,47 & 2,73 & 2,27 & 2,67 & 2,53 & 2,87 \\
\hline 12 & 52303932 & $a$ & 11 & 69,47 & 3,00 & 3,00 & 2,83 & 3,00 & 2,92 & 3,25 & 3,17 & 3,08 \\
\hline 13 & 52000211 & $a$ & 9 & 81,72 & 3,00 & 2,86 & 2,86 & 3,00 & 3,14 & 3,14 & 3,14 & 3,00 \\
\hline
\end{tabular}

Tabel 2. Data matakuliah, kehadiran, dan penilaian mahasiswa

6 Kusumadew i - Fuzzy Q uantification Theory I untuk A nalisis H ubungan A ntara Penilaian Kinerja ... 


\begin{tabular}{|c|c|c|c|c|c|c|c|c|c|c|c|c|}
\hline 14 & 52000211 & b & 9 & 87,50 & 3,63 & 3,13 & 3,50 & 3,25 & 3,13 & 3,38 & 3,13 & 3,00 \\
\hline 15 & 52000211 & c & 9 & 83,33 & 3,64 & 3,57 & 3,43 & 3,36 & 3,43 & 3,50 & 3,29 & 3,21 \\
\hline 16 & 10000811 & a & 12 & 81,25 & 3,57 & 3,43 & 3,36 & 3,14 & 3,14 & 3,36 & 3,43 & 3,43 \\
\hline 17 & 10000811 & b & 12 & 88,89 & 3,40 & 3,53 & 3,20 & 3,33 & 3,27 & 3,53 & 3,33 & 3,20 \\
\hline 18 & 10000811 & c & 11 & 60,00 & 3,77 & 3,77 & 3,00 & 3,38 & 3,38 & 3,54 & 3,31 & 3,46 \\
\hline 19 & 52303241 & a & 9 & 33,75 & 3,13 & 2,67 & 2,47 & 2,73 & 2,73 & 3,00 & 3,13 & 3,13 \\
\hline 20 & 52303241 & b & 10 & 50,55 & 2,67 & 2,73 & 2,67 & 2,87 & 2,67 & 2,87 & 2,87 & 3,00 \\
\hline 21 & 52303241 & c & 9 & 44,44 & 2,60 & 2,33 & 2,47 & 2,80 & 2,53 & 2,73 & 2,93 & 2,87 \\
\hline
\end{tabular}

Tabel 2. Ianjutan

\begin{tabular}{|c|c|c|c|c|c|c|c|c|c|c|c|c|}
\hline \multirow{2}{*}{ No } & \multirow{2}{*}{$\begin{array}{c}\text { Kode } \\
\text { matakuliah }\end{array}$} & \multirow{2}{*}{ Kelas } & \multirow{2}{*}{$\begin{array}{l}\text { Jumlah } \\
\text { kehadiran }\end{array}$} & \multirow{2}{*}{$\begin{array}{c}\text { \%Lulus } \\
>=\mathrm{B}\end{array}$} & \multicolumn{8}{|c|}{ Hasil penilaian mahasiswa* } \\
\hline & & & & & N1 & N2 & N3 & N4 & N5 & N6 & N7 & N8 \\
\hline 22 & 52303241 & $\mathrm{~d}$ & 10 & 55,56 & 2,79 & 2,36 & 2,21 & 2,50 & 2,71 & 2,71 & 2,64 & 2,86 \\
\hline 23 & 52301931 & $a$ & 12 & 59,21 & 2,17 & 2,08 & 2,42 & 2,75 & 2,17 & 3,00 & 3,00 & 3,00 \\
\hline 24 & 52301931 & $\mathrm{~b}$ & 12 & 56,25 & 2,80 & 2,67 & 2,67 & 3,00 & 2,73 & 3,13 & 3,20 & 3,27 \\
\hline 25 & 52301931 & C & 12 & 49,37 & 2,27 & 2,20 & 2,13 & 2,73 & 2,53 & 3,27 & 3,20 & 3,13 \\
\hline 26 & 52301931 & $\mathrm{~d}$ & 12 & 68,75 & 2,20 & 2,27 & 2,33 & 2,60 & 2,07 & 2,87 & 3,40 & 2,93 \\
\hline 27 & 52304732 & - & 10 & 48,48 & 2,79 & 2,43 & 2,71 & 2,86 & 2,64 & 3,00 & 3,00 & 2,93 \\
\hline 28 & 61100221 & & 12 & 23,53 & 3,13 & 3,00 & 2,80 & 3,00 & 2,73 & 2,40 & 3,27 & 3,00 \\
\hline 29 & 61100221 & $\mathrm{~b}$ & 12 & 26,42 & 3,07 & 3,07 & 2,93 & 3,13 & 3,00 & 3,40 & 3,47 & 3,20 \\
\hline 30 & 6110 & C & 12 & 48,75 & 2,60 & 2,70 & 2,80 & 2,80 & 2,60 & 2,80 & 1,70 & 2,80 \\
\hline 31 & 6110 & $d$ & 12 & 51,25 & 2,50 & 2,50 & 2,50 & 2,70 & 2,50 & 2,80 & 1,20 & 2,70 \\
\hline 32 & 52304832 & $a$ & 10 & 25,64 & 3,00 & 3,13 & 3,20 & 3,20 & 2,80 & 3,00 & 2,87 & 3,00 \\
\hline 33 & 52304932 & $a$ & 10 & 60,00 & 2,70 & 2,50 & 2,60 & 2,90 & 2,70 & 3,00 & 2,90 & 3,00 \\
\hline 34 & 52304632 & $a$ & 10 & 38,46 & 3,33 & 3,20 & 2,87 & 3,20 & 3,13 & 3,40 & 3,20 & 3,40 \\
\hline 35 & 52301021 & $a$ & 11 & 32,86 & 2,73 & 2,09 & 2,36 & 2,73 & 2,36 & 2,91 & 3,00 & 2,82 \\
\hline 36 & 52301021 & b & 12 & 40,59 & 3,13 & 2,80 & 2,73 & 3,00 & 2,73 & 3,20 & 3,33 & 3,27 \\
\hline 37 & 5230 & & 11 & 42,27 & 2,78 & 2,44 & 2,44 & 3,00 & 2,89 & 3,00 & 3,11 & 3,11 \\
\hline 38 & 523 & & 10 & 40,00 & 3,08 & 3,15 & 2,62 & 3,08 & 2,77 & 2,92 & 2,46 & 3,15 \\
\hline 39 & 523 & & 11 & 33,75 & 3,36 & 3,21 & 3,00 & 3,14 & 2,93 & 3,14 & 3,29 & 3,21 \\
\hline 40 & 52300621 & & 9 & 43,00 & 2,25 & 1,75 & 1,88 & 2,38 & 2,00 & 3,25 & 3,13 & 3,00 \\
\hline 41 & 52300621 & $\bar{d}$ & 9 & 31,58 & 2,13 & 2,13 & 2,27 & 2,27 & 2,13 & 2,73 & 2,00 & 2,53 \\
\hline 42 & 52300831 & a & 10 & 83,33 & 2,40 & 1,60 & 2,00 & 2,40 & 2,00 & 2,87 & 2,67 & 2,80 \\
\hline 43 & 52300831 & $\mathrm{~b}$ & 10 & 89,33 & 1,83 & 1,67 & 1,67 & 1,92 & 1,67 & 2,42 & 2,17 & 2,50 \\
\hline 44 & 52300831 & C & 7 & 48,89 & 2,86 & 2,71 & 2,57 & 2,71 & 2,57 & 3,14 & 2,86 & 3,14 \\
\hline 45 & 52300831 & $\mathrm{~d}$ & 7 & 12,50 & 3,00 & 3,14 & 3,00 & 3,43 & 2,43 & 3,14 & 3,29 & 3,14 \\
\hline 46 & 10001011 & $a$ & 12 & 39,13 & 3,00 & 3,08 & 2,83 & 3,08 & 3,00 & 2,92 & 2,58 & 3,08 \\
\hline 47 & & b & 12 & 40,00 & 3,14 & 3,14 & 3,00 & 3,14 & 3,00 & 2,86 & 2,71 & 3,00 \\
\hline 48 & & & 12 & 36,99 & 3,00 & 2,89 & 2,78 & 2,78 & 2,89 & 2,78 & 3,00 & 2,89 \\
\hline 49 & & & 11 & 36,76 & 2,93 & 2,87 & 2,60 & 3,13 & 2,47 & 3,07 & 2,60 & 3,13 \\
\hline 50 & 5230 & b & 11 & 22,22 & 3,07 & 2,93 & 2,79 & 3,07 & 2,93 & 3,14 & 2,93 & 2,93 \\
\hline 51 & 431 & & 12 & 56,94 & 3,13 & 2,93 & 2,60 & 3,07 & 2,87 & 3,27 & 2,80 & 3,13 \\
\hline 52 & 52303431 & 0 & 11 & 36,99 & 3,14 & 3,14 & 2,86 & 3,07 & 2,86 & 3,29 & 3,29 & 3,21 \\
\hline 53 & 52302131 & $a$ & 10 & 52,17 & 3,07 & 2,73 & 3,07 & 3,07 & 2,80 & 3,00 & 2,67 & 3,13 \\
\hline 54 & 52302131 & $\mathrm{~b}$ & 12 & 55,41 & 3,00 & 3,07 & 3,13 & 2,93 & 2,80 & 3,13 & 2,87 & 3,00 \\
\hline 55 & 52302131 & C & 10 & 48,57 & 2,93 & 2,80 & 3,00 & 2,87 & 2,80 & 2,80 & 2,67 & 2,87 \\
\hline 56 & 52302131 & $\mathrm{~d}$ & 10 & 55,71 & 3,27 & 3,33 & 3,20 & 2,87 & 2,87 & 3,33 & 2,87 & 3,13 \\
\hline 57 & 52302331 & $a$ & 8 & 93,00 & 2,93 & 2,73 & 2,67 & 3,07 & 2,67 & 2,87 & 3,00 & 2,93 \\
\hline 58 & 52302021 & $a$ & 12 & 9,33 & 2,63 & 2,50 & 2,88 & 3,00 & 2,13 & 3,00 & 3,25 & 3,00 \\
\hline 59 & 52302021 & $\mathrm{~b}$ & 12 & 5,00 & 2,53 & 2,47 & 2,20 & 2,93 & 2,47 & 3,07 & 3,60 & 3,07 \\
\hline 60 & 52302021 & c & 12 & 11,94 & 3,15 & 2,69 & 2,46 & 3,15 & 2,69 & 3,46 & 3,69 & 3,31 \\
\hline 61 & 52302021 & $d$ & 11 & 41,18 & 3,50 & 3,42 & 3,00 & 3,08 & 3,08 & 3,25 & 3,17 & 3,17 \\
\hline 62 & 52305032 & $a$ & 10 & 53,76 & 2,80 & 2,67 & 2,73 & 2,53 & 2,47 & 2,73 & 2,73 & 3,00 \\
\hline 63 & 52305232 & $a$ & 9 & 28,99 & 3,07 & 2,60 & 2,53 & 3,20 & 2,93 & 3,27 & 3,20 & 3,27 \\
\hline 64 & 52305132 & $a$ & 10 & 42,11 & 3,10 & 3,00 & 2,80 & 3,10 & 2,90 & 3,00 & 3,10 & 2,90 \\
\hline 65 & & $a$ & 10 & 60,00 & 2,82 & 2,82 & 2,73 & 3,00 & 2,55 & 2,91 & 2,45 & 8 \\
\hline
\end{tabular}




\begin{tabular}{|c|c|c|c|c|c|c|c|c|c|c|c|c|}
\hline 66 & 52301731 & a & 9 & 39,47 & 2,27 & 2,20 & 2,20 & 1,93 & 2,13 & 2,80 & 2,07 & 2,60 \\
\hline 67 & 52301731 & b & 8 & 62,65 & 2,63 & 2,50 & 2,38 & 3,00 & 2,50 & 3,00 & 2,63 & 3,13 \\
\hline 68 & 52301731 & c & 8 & 57,14 & 2,71 & 2,43 & 2,71 & 3,00 & 2,43 & 3,00 & 3,00 & 3,14 \\
\hline 69 & 52301731 & d & 9 & 24,05 & 2,85 & 2,77 & 3,00 & 3,08 & 2,92 & 3,23 & 2,85 & 3,31 \\
\hline 70 & 52304232 & a & 6 & 43,14 & 2,87 & 2,53 & 2,53 & 3,13 & 2,40 & 2,73 & 2,40 & 2,73 \\
\hline 71 & 52304132 & a & 11 & 48,31 & 3,14 & 3,00 & 2,79 & 3,07 & 2,79 & 3,07 & 3,00 & 2,93 \\
\hline 72 & 52304432 & a & 11 & 27,03 & 2,92 & 3,00 & 2,58 & 2,67 & 2,92 & 2,83 & 2,67 & 2,92 \\
\hline 73 & 52304032 & a & 9 & 16,00 & 2,40 & 2,53 & 2,27 & 2,87 & 2,33 & 3,07 & 2,87 & 2,87 \\
\hline
\end{tabular}

Tabel 2. Ianjutan

\begin{tabular}{|c|c|c|c|c|c|c|c|c|c|c|c|c|}
\hline \multirow{2}{*}{ No } & Kode & \multirow{2}{*}{ Kelas } & \multirow{2}{*}{$\begin{array}{c}\text { Jumlah } \\
\text { matakuliah }\end{array}$} & KLulus & \multicolumn{6}{|c|}{ Hasil penilaian mahasiswa* } \\
\cline { 7 - 13 } & & kehadiran & >=B & N1 & N2 & N3 & N4 & N5 & N6 & N7 & N8 \\
\hline 74 & 52304332 & $\mathrm{a}$ & 12 & 82,42 & 3,43 & 3,29 & 2,93 & 3,07 & 2,71 & 3,14 & 3,79 & 2,93 \\
\hline 75 & 52301831 & $\mathrm{a}$ & 10 & 48,0519 & 2,92 & 2,67 & 2,75 & 3,00 & 2,50 & 3,00 & 2,92 & 3,08 \\
\hline 76 & 52301831 & $\mathrm{~b}$ & 11 & 56,6265 & 2,86 & 2,86 & 2,86 & 3,07 & 2,86 & 3,36 & 3,00 & 3,21 \\
\hline 77 & 52301831 & $\mathrm{c}$ & 10 & 45,679 & 2,90 & 2,60 & 3,20 & 3,00 & 2,70 & 3,00 & 3,00 & 3,10 \\
\hline 78 & 52301831 & $\mathrm{~d}$ & 10 & 49,3827 & 2,69 & 2,75 & 2,88 & 3,06 & 2,44 & 2,75 & 2,50 & 2,94 \\
\hline
\end{tabular}

Keterangan:

*) Rata-rata hasil penilaian mahasiswa melalui kuisioner, dengan skala 1 (buruk) sampai 4 (sangat baik), yang meliputi faktor-faktor:

$\mathrm{N} 1$ : Kejelasan dan semangat dosen dalam memberikan kuliah

N2: Kemampuan dosen menguasai kelas

N3: Kemampuan dosen mendorong mahasiswa untuk berperan aktif

N4: Tanggapan dan kejelasan dosen menjawab pertanyaan mahasiswa

N5: Kemampuan dosen memotivasi mahasiswa untuk belajar

N6: Hubungan contoh soal dan tugas dengan materi yg diberikan

N7 : Disiplin dosen terhadap alokasi waktu yang diberikan

N8: Kesesuaian materi kuliah dengan silabus/ Satuan Acara Perkualiahan (SAP)

Untuk membentuk Tabel 1, nilai $y_{k}$ diperoleh dari \%Lulus >=B untuk data kek; nilai $\mu_{\mathrm{i}}(\mathrm{k})$ pada setiap kategori kei (dalam kasus ini hanya menggunakan 1 kategori, yaitu kehadiran dosen) diperoleh dari persamaan (26) berikut:

$$
\mu_{1}(k)=\frac{H \operatorname{adir}(\mathrm{k})}{12}
$$

Sedangkan nilai $\mu_{B}(k)$ pada setiap fuzzy group kej $(j=1,2, \ldots, 8)$ diperoleh dari persamaan (27) berikut:

$$
\mu_{\mathrm{B}}(\mathrm{k})=\frac{\mathrm{N}_{\mathrm{B}} \mathrm{j}(\mathrm{k})}{12}
$$

\subsection{Penyelesaian dengan Fuzzy Q uantification Theory I}

Dengan menggunakan regresi linear bisa diperoleh hubungan antara kehadiran dosen mengajar $(\mathrm{x})$ dengan nilai kelulusan mahasiswa $\geq$ ' $\mathrm{B}$ ' ( $\mathrm{y}$ ) tanpa mempertimbangkan faktor-faktor lainnya, sebagai:

$$
\begin{aligned}
& y=-27,3988 \mu[x]+69,8126 \\
& \text { atau } \\
& y=-2,2832 x+69,8126
\end{aligned}
$$

dengan koefisien korelasi sebesar -0,142; yang berarti bahwa banyaknya kehadiran dosen tidak berkorelasi dengan nilai kelulusan mahasiswa $\geq$ 'B'.

8 Kusumadew i - Fuzzy Q uantification Theory I untuk A nalisis H ubungan A ntara Penilaian Kinerja ... 
Untuk setiap fuzzy group ke-i $(i=1,2, \ldots, 8)$, dengan menggunakan persamaan (9) (10) dan (11), diperoleh vektor y' yang merupakan hasil transpos dari vektor baris y (nilai kelulusan mahasiswa $\geq$ 'B'). Matriks G, merupakan matriks bujursangkar berukuran 78x78 dengan elemen-elemen diagonalnya berisi $\mu_{B}(k)$, nilai keanggotaan data ke-k pada fuzzy group $B$ ke-i dan elemen-elemen lainnya nol. Matriks $X$, hanya berukuran $78 \times 1$ dengan elemen baris ke-k adalah $\mu_{1}(k)$ berisi derajat keanggotaan sampel ke-k pada kehadiran dosen mengajar. Sedangkan y, adalah vektor berukuran 78x1 dengan elemen baris ke-k adalah nilai kelulusan mahasiswa $\geq$ ' $B$ '.

Vektor bobot kategori (a) hanya berisi satu elemen, yang dapat diperoleh dengan persamaan (15) . Tabel 3 menunjukan bobot kategori a.

Tabel 3 Bobot kategori.

\begin{tabular}{|l|c|c|}
\hline \multirow{2}{*}{ Fuzzy group } & \multicolumn{2}{|c|}{ Bobot kategori } \\
\cline { 2 - 3 } & $\begin{array}{c}\text { sebagai koefisien } \\
\mu[\mathrm{x}]\end{array}$ & $\begin{array}{c}\text { sebagai koefisien } \\
\mathrm{x}\end{array}$ \\
\hline $\begin{array}{l}\text { Kejelasan dan semangat dosen dalam } \\
\text { memberikan kuliah }\end{array}$ & 51,1883 & 4,2657 \\
\hline Kemampuan dosen menguasai kelas & 50,8074 & 4,2339 \\
\hline $\begin{array}{l}\text { Kemampuan dosen mendorong mahasiswa } \\
\text { untuk berperan aktif }\end{array}$ & 51,3311 & 4,2776 \\
\hline $\begin{array}{l}\text { Tanggapan dan kejelasan dosen menjawab } \\
\text { pertanyaan mahasiswa }\end{array}$ & 50,6966 & 4,2247 \\
\hline $\begin{array}{l}\text { Kemampuan dosen memotivasi mahasiswa } \\
\text { untuk belajar }\end{array}$ & 50,9738 & 4,2478 \\
\hline $\begin{array}{l}\text { Hubungan contoh soal dan tugas dengan } \\
\text { materi yg diberikan }\end{array}$ & 51,0274 & 4,2522 \\
\hline $\begin{array}{l}\text { Disiplin dosen terhadap al okasi waktu yang } \\
\text { diberikan }\end{array}$ & 50,6831 & 4,2236 \\
\hline $\begin{array}{l}\text { Kesesuaian materi kuliah dengan } \\
\text { silabus/ Satuan Acara Perkualiahan (SAP) }\end{array}$ & 50,7656 & 4,2305 \\
\hline
\end{tabular}

Sehingga, dari persamaan (1) diperoleh nilai eksternal data $\left(y_{i}\right)$ untuk setiap fuzzy group ke-i:

$\begin{array}{lll}\mathrm{y}_{1}=51,1883 \mu[\mathrm{x}] ; & \text { atau } & \mathrm{y}_{1}=4,2657 \mathrm{x} ; \\ \mathrm{y}_{2}=50,8074 \mu[\mathrm{x}] ; & \text { atau } & \mathrm{y}_{2}=4,2339 \mathrm{x} ; \\ \mathrm{y}_{3}=51,3311 \mu[\mathrm{x}] ; & \text { atau } & \mathrm{y}_{3}=4,2776 \mathrm{x} ; \\ \mathrm{y}_{4}=50,6966 \mu[\mathrm{x}] ; & \text { atau } & \mathrm{y}_{4}=4,2247 \mathrm{x} ; \\ \mathrm{y}_{5}=50,9738 \mu[\mathrm{x}] ; & \text { atau } & \mathrm{y}_{5}=4,2478 \mathrm{x} ; \\ \mathrm{y}_{6}=51,0274 \mu[\mathrm{x}] ; & \text { atau } & \mathrm{y}_{6}=4,2522 \mathrm{x} ; \\ \mathrm{y}_{7}=50,6831 \mu[\mathrm{x}] ; & \text { atau } & \mathrm{y}_{7}=4,2236 \mathrm{x} \\ \mathrm{y}_{8}=50,7656 \mu[\mathrm{x}] ; & \text { atau } & \mathrm{y}_{8}=4,2305 \mathrm{x} ;\end{array}$

Koefisien korelasi antara nilai eksternal data pada setiap fuzzy group $\left(\mathrm{y}_{\mathrm{i}}\right)$ dengan nilai kelulusan mahasiswa $\geq$ ' $B$ ' sama dengan 1 , yang berarti bahwa setiap 
fuzzy group memiliki korelasi yang sangat kuat dengan nilai kelulusan mahasiswa $\geq$ 'B'.

Pada Tabel 3 terlihat bahwa bobot kategori terbesar terjadi pada faktor kemampuan dosen mendorong mahasiswa untuk berperan aktif. Hal ini berarti bahwa faktor kemampuan dosen mendorong mahasiswa untuk berperan aktif memiliki pengaruh yang paling tinggi diantara faktor-faktor yang lainnya dalam kaitannya dengan pengaruh antara kehariran dosen mengajar dengan nilai kelulusan mahasiswa $\geq$ ' $B$ '. Sedangkan bobot kategori terkecil terjadi pada faktor disiplin dosen terhadap alokasi waktu yang diberikan. Hal ini berarti bahwa faktor disiplin dosen terhadap alokasi waktu yang diberikan memiliki pengaruh yang paling rendah diantara faktor-faktor yang lainnya dalam kaitannya dengan pengaruh antara kehariran dosen mengajar dengan nilai kelulusan mahasiswa $\geq$ 'B'.

Untuk setiap fuzzy group, titik potong nilai eksternal data dengan persamaan (28) mendekati titik $(0,89 ; 45)$. Hal ini berarti bahwa setiap fuzzy group akan memberikan pengaruh yang sangat berarti apabila jumlah kehadiran dosen mengajar lebih dari $(0,89 \times 12)=10$ kali. Untuk jumlah kehadiran lebih dari 10 kali, maka setiap fuzzy group akan memberikan korelasi positif dengan prosentase nilai kelulusan mahasiswa $\geq$ 'B' mencapai angka lebih dari $45 \%$.

\section{SIM PULAN}

Berdasarkan hasil penelitian, dapat disimpulkan bahwa:

a. Penilaian mahasiswa terhadap kinerja dosen yang diberikan secara kualitatif sangat mempengaruhi pengaruh kehadiran dosen terhadap nilai kelulusan mahasiswa $\geq$ ' $B$ '.

b. Faktor utama yang paling berpengaruh adalah kemampuan dosen mendorong mahasiswa untuk berperan aktif, yang berarti bahwa Jurusan Teknik Informatika harus mengupayakan suatu metode baru dalam proses belajar mengajar yang lebih mengutamakan peran mahasiswa dalam proses belajar mengajar tersebut.

c. Faktor-faktor kualitatif tersebut akan sangat berpengaruh apabila kehadiran dosen mengajar lebih dari 10 kali, yang berarti bahwa kedepan Jurusan Teknik Informatika harus lebih mengupayakan cara untuk meningkatkan kedisiplinan dosen untuk hadir mengajar.

\section{PUSTAKA}

Kusumadewi, S.. (2004). Aplikasi Logika Fuzzy Untuk Pendukung Keputusan. Yogyakarta: Graha Ilmu.

Terano, T., Asai, K., dan Sugeno, M. (1992). Fuzzy Systems Theory and Its A pplications. London: Academic Press. 